УДК $351 / 354$

DOI https://doi.org/10.32836/2310-9653-2020-3.4

Н. В. Щербак, кандидат наук з державного управління, головний науковий співробітник

Інституту законодавства Верховної Ради України

\title{
СУЧАСНИЙ СТАН ТА ПЕРСПЕКТИВИ РОЗВИТКУ НАЦІОНАЛЬНОГО ЗАКОНОДАВСТВА 3 ПИТАНЬ ГЕНДЕРНОЇ РІВНОСТІ (В УМОВАХ РЕФОРМУВАННЯ СИСТЕМИ ДЕРЖАВНОГО УПРАВЛІННЯ ТА РЕАЛІЗАЦІї ПАРЛАМЕНТСЬКОЇ РЕФОРМИ)
}

У статті досліджено актуальні питання розвитку національного законодавства з питань гендерної рівності. Аргументовано, щчо особливого значення ці питання набувають в умовах реформування системи державного управління та реалізації парламентської реформи в Україні. Одночасно доведено, щзо питання рівноправності жінок $і$ чоловіків гарантовано в Україні як Конституцією, так і іншими актами законодавства. Важливим завданням є забезпечення інтеграції гендерного підходу до усіх напрямів державної політики.

Усебічно проаналізовано основні міжнародні акти з питань забезпечення гендерної рівності, а також сучасний стан iї практичного упровадження. Наголошено, щзо питання розвитку національного законодавства з питань тендерної рівності є досить складним та комплексним поняттям, воно включає різні галузі, а саме: галузь безпеки та оборони, галузь подолання дискримінації та домашнього насильства тощэ. Підкреслено, щңо гендерна рівність - ие рівний правовий статус жінок $i$ чоловіків та рівні можливості для його реалізаиії, щчо дає змогу особам обох статей брати рівну участь у всіх сферах суспільного життя. У зв 'язку із иим всебічно проаналізовано державний механізм забезпечення гендерної рівності як впорядкованоі системи міжнародних, національних, регіональних і місцевих організаиійних структур держсавного і громадського характеру, діяльність яких спрямована на утвердження принципів тендерної рівності у різних сферах суспільного життя та гарантування здійснення вироблених ними гендерних стратегій і відповідної до них державної гендерної політики.

На основі проведеного дослідження вироблено практичні рекомендаиії щзоо практичного упровадження стандартів гендерної рівності у діяльність Верховної Ради України та органів місиевого самоврядування із урахуванням основних завдань парламентської реформи та реформи державного управління, які передбачають формування гендерних квот та забезпечення рівного представництва чоловіків та жінок в органах влади на усіх рівнях.

Ключові слова: законодавство, гендер, гендерна рівність, стандарт, державне управління, реформа, Уряд, Парламент, модернізація.

N. V. Shcherbak. Current status and perspectives for development of the national legislation in the field of gender equality (in the framework of the public administration reform and the parliamentary reform implementation)

The article provides a deep analysis of the issues related to the development of the national legislation in the field of gender equality. It is justified that this issue becomes extremely important in the framework of the public administration reform and the parliamentary reform implementation in Ukraine. It is explained that gender equality issues are secured by the Constitution of Ukraine as well as other pieces of the national legislation. An important objective is to ensure the integration of the gender approach in all directions of the State policy.

It is noted that "gender" is a complex notion and there are different definitions in the scientific literature. It includes the different aspects from the different fields (spheres), i.e.: sphere of security and defense, sphere of overcoming discrimination and domestic violence. It is underlined that the gender equality is also equal legal status of women and men as well as equal opportunities for its realization. It allows the possibility for the representatives of both sexes to have equal right regarding their participation in all spheres of the public life. Taking into account the above-mentioned, it is analyzed the State mechanism for ensuring gender equality as a well-structured system of the international, national, regional and local organizational structures (of public or civic importance) focused on the consolidation of the gender equality principles in all spheres of the public life and the practical implementation of the developed gender strategies (according to the defined objectives of the State gender policy).

On the basis of the conducted research, it is developed the practical recommendations regarding further implementation of the gender equality standards in the activity of the Verkhovna Rada of Ukraine and the local self-government bodies, taking into account the main goals of the public administration and the parliamentary reforms (in particular, regarding keeping gender quota and ensuring equal representation of men and women in all public institutions at all levels of State power).

Key words: legislation, gender, gender equality, standard, public administration, reform, government, parliament, modernization.

Постановка проблеми. Сучасна державна політика України спрямована на досягнення рівності жінок і чоловіків у суспільстві, подолання всіх форм дискримінації, зокрема за ознакою статі, створення необхідних соціальних і політичних передумов для реалізації прав та можливостей жінок і чоловіків у всіх сферах трудового, суспільного та особистого життя. Вагому роль у формуванні та реалізації гендерної політики відіграє держава, яка створює механізми для досягнення гендерної рівності. 
В Україні на сьогодні здійснюються широкомасштабна реформа державного управління, яка спрямована на модернізацію діяльності усіх органів державної влади (у тому числі й Верховної Ради України та їі Апарату), а також розбудови їх кадрового та інституційного потенціалу відповідно до європейських стандартів та кращих практик інших країн.

Враховуючи основні положення Угоди про асоціацію між Україною та Свропейським Союзом, ратифікованої Законом України від 16 вересня 2014 р. № 1678-VII, у лютому 2016 року Місія Свропейського парламенту з оцінки потреб розробила і презентувала Доповідь та Дорожню карту щодо підвищення інституційної спроможності Верховної Ради України, окремі рекомендації якої безпосередньо стосуються питань упровадження стандартів гендерної рівності у діяльність Українського Парламенту та його Апарату [1].

Постанова Верховної Ради від 17 березня 2016 року «Про заходи з реалізації рекомендацій щодо внутрішньої реформи та підвищення інституційної спроможності Верховної Ради України» [5], прийнята на підставі рекомендацій Місії Свропейського парламенту, задекларувала пріоритетні напрями проведення внутрішньої реформи, розбудови кадрового та інституційного потенціалу Українського Парламенту та його Апарату. У зв'язку із цим одним із найбільш важливих завдань має стати упровадження стандартів гендерної рівності як на політичному, так і на адміністративному рівнях.

Одночасно слід зазначити, що важливим чинником для упровадження стандартів гендерної рівності в усіх органах державної влади стало ухвалення Стратегії реформування державного управління України, затвердженої розпорядженням Кабінету Міністрів України від 24 червня 2016 року № 474-р, а також введення в дію нової редакції Закону України «Про державну службу» [2]. Разом із тим зарубіжний досвід та кращі практики інших країн свідчать про те, що стандарти гендерної рівності (зокрема, щодо рівного представництва чоловіків та жінок в усіх органах влади) мають важливими складовими елементами в подальшій реалізації реформи державного управління та парламентської реформи в Україні.

Аналіз останніх досліджень і публікацій. В останні роки питанням гендеру, реалізації різних аспектів гендерної політики почала приділятися значна увага як з боку науковців, так і практиків. Істотний внесок у дослідження цих та інших питань проблем зробили М. Білинська, В. Гошовська, М. Канавець, Лихач, А. Малюга, Т. Марценюк, В. Мироненко, Н. Нижник, О. Руденко, О. Синчак та ін.

Одночасно питання розвитку національного законодавства 3 питань забезпечення гендерної рівності залишаються ще недостатньо вивченими. У зв'язку із цим та з урахуванням завдань широкомасштабної реформи державного управління та парламентської реформи, що реалізуються на сьогодні в Україні, є актуальним та необхідним завданням продовжити вивчення різних аспектів розширення представництва жінок в органах влади на усіх рівнях (насамперед, у Верховній Раді України), а також забезпечення подальшого розвитку національного законодавства з урахуванням міжнародних стандартів та кращих практик інших зарубіжних країн у цій сфері.

Виокремлення невирішених раніше частин загальної проблеми. Дослідження наукою державного управління таких питань, як гендер та гендерна політика, є досить складним та комплексним завданням. По-перше, наука державне управління - це досить нова галузь у спектрі гуманітарного циклу української науки; вона не просто є міждисциплінарною, а є новою в силу тих кардинальних змін, які відбуваються в посттоталітарному суспільстві. По-друге, українські політики та державні службовці тільки вчаться активно упроваджувати у своїй поточній діяльності стандарти гендерної рівності, зокрема в процесі реалізації реформи державного управління. Слід констатувати, що міжнародні стандарти з питань гендерної рівності досі залишаються маловідомими як для управлінців, так і для більшості українських громадян, що значно ускладнює його подальше впровадження в національне законодавство з метою забезпечення його подальшого розвитку та модернізації.

Метою статті є дослідження актуальних питань розвитку національного законодавства 3 питань гендерної рівності, зокрема в контексті реформування системи державного управління та реалізації парламентської реформи в Україні.

Виклад основного матеріалу. Поняття «гендер» може бути визначено як змодельована суспільством та підтримувана соціальними інститутами система цінностей, норм і характеристик чоловічої й жіночої поведінки, стилю життя та способу мислення, ролей та відносин жінок і чоловіків, набутих ними як особистостями в процесі соціалізації, що насамперед визначається соціальним, політичним, економічним і культурним контекстами буття й фіксує уявлення про жінку та чоловіка залежно від їх статі [10].

Одним із найбільш пріоритетних завдань реалізації державної гендерної політики в Україні на сучасному етапі є створення нормативно-правової бази з питань гендерної рівності, яка поступово приводиться у відповідність до міжнародних стандартів.

Головним нормативно-правовим актом України, спрямованим на реалізацію жінками та чоловіками своїх рівних прав і можливостей, є Конституція України, якою закріплено рівність прав жінок і чоловіків. Стаття 24 Конституції України гарантує, що «Громадяни мають рівні конституційні права і свободи та є рівними перед законом» [6].

На розвиток вказаних положень Конституції України у 2005 році було прийнято спеціальний законодавчий акт з гендерної проблематики - Закон України «Про забезпечення рівних прав та можливостей жінок і чоловіків», 
який став практичним втіленням головних принципів рівності статей. Зазначений Закон став початком розвитку національного законодавства у сфері забезпечення рівних прав і можливостей жінок і чоловіків. Надалі, $з$ метою приведення у відповідність до прийнятого закону, вносилися зміни до інших законів, а також ухвалювалися відповідні нормативно-правові акти, спрямовані на розвиток національного механізму забезпечення рівних прав і можливостей тощо.

Указ Президента України від 26 липня 2005 року № 1135/2005 передбачив покладання виконання обов’язків щодо забезпечення рівних прав та можливостей жінок і чоловіків на одного із заступників міністрів, керівників інших центральних та місцевих органів виконавчої та визначив їх повноваження у цій сфері, а саме:

- забезпечення надання жінкам і чоловікам рівних прав та можливостей у відповідній сфері діяльності;

- співробітництво з громадськими організаціями, зокрема громадськими жіночими організаціями, для узагальнення інформації щодо стану забезпечення визначення шляхів рівних прав та можливостей жінок і чоловіків та запобігання виникненню дискримінації за ознакою статі;

- сприяння створенню рівних умов для поєднання жінками і чоловіками професійних і сімейних обов'язків, у тому числі шляхом розвитку соціальних послуг;

- здійснення заходів, спрямованих на формування гендерної культури населення, провадження відповідної інформаційно-пропагандистської діяльності;

- забезпечення додержання законодавства щодо рівності прав та можливостей жінок і чоловіків;

- розгляд та проведення аналізу звернень громадян із питань забезпечення рівних прав та можливостей жінок і чоловіків;

- організація систематичного навчання посадових осіб центральних та місцевих органів виконавчої влади із зазначених питань;

- впровадження гендерних підходів до організації роботи центральних та місцевих органів виконавчої влади з урахуванням досвіду інших держав.

Законодавча база України щодо гендерної рівності включає також Стратегію та План дій у сфері прав людини, прийняті у 2015 році, метою яких є гарантування рівних прав та можливостей для жінок та чоловіків в усіх сферах життя. Серед ключових напрямів Національної стратегії у сфері прав людини визначені такі, що сприятимуть забезпеченню пріоритетності прав і свобод людини як визначального чинника під час визначення державної політики, прийняття рішень із забезпечення рівних прав та можливостей жінок і чоловіків. Зазначеним документом також визнається наявність в Україні нерівності прав та можливостей жінок і чоловіків, що зумовлює необхідність продовження активної та комплексної роботи щодо розв'язання проблем гендерної дискримінації та забезпечення реальної ґендерної рівності. Стратегічною метою є забезпечення рівних прав та можливостей жінок і чоловіків в усіх сферах життя суспільства.

План дій із реалізації Національної стратегії у сфері прав людини на період до 2020 року, прийнятий Урядом містить 135 пунктів та, зокрема, передбачає такі заходи: визначення засобів захисту від неналежних умов тримання під вартою; забезпечення якісної і доступної правової допомоги через адвокатуру та ефективну систему безоплатної правової допомоги тощо.

Крім того, Уряд своєю постановою від 7 червня 2017 року № 390 запровадив посаду Урядового уповноваженого з питань гендерної політики та затвердив відповідне Положення.

3 метою підвищення рівня дотримання принципу забезпечення рівних прав та можливостей жінок і чоловіків у всіх сферах життя українського суспільства у 2018 році затверджено Державну соціальну програму забезпечення рівних прав та можливостей жінок і чоловіків на період до 2021 року. Програмою визначено основні завдання, спрямовані на підвищення рівня дотримання принципу забезпечення рівних прав та можливостей жінок і чоловіків у всіх сферах життя українського суспільства.

До реалізації Програми, крім органів державної влади і місцевого самоврядування, залучені міжнародні організації та громадські об'єднання, діяльність яких спрямовується на забезпечення рівних прав та можливостей жінок і чоловіків. На виконання Програми станом на 2019 рік прийнято 4 обласні програми, а також 16 комплексних програм, які включають даний компонент.

На всіх етапах реалізації Стратегії реформування державного управління України на період до 2021 року, схваленої розпорядженням Кабінету Міністрів України від 24 червня 2016 року № 474-р передбачено здійснення відповідних заходів щодо забезпечення гендерної рівності як складової частини принципів державного управліннях. Стратегія спрямована на розв'язання й гендерного дисбалансу у сфері державної служби та управління людськими ресурсами.

Прийнятий на виконання зазначеної стратегії Закон України «Про державну службу» визначає, що державна служба здійснюється з дотриманням принципу «забезпечення рівного доступу до державної служби - заборони всіх форм і проявів дискримінації, відсутності необгрунтованих обмежень або надання необгрунтованих переваг певним категоріям громадян під час вступу на державну службу» (пункт 7 частини першої статті 4). Таким чином, гендерний паритет на державній службі має постати збалансованою участю жінок та чоловіків у процесах державного управління. 
Підтримуючи проголошені резолюцією Генеральної Асамблеї Організації Об’єднаних Націй від 25 вересня 2015 року № 70/1 глобальні цілі сталого розвитку до 2030 року та результати їх адаптації з урахуванням специфіки розвитку держави, Указом Президента України від 30 вересня 2019 року № 722/2019 затверджено Цілі сталого розвитку України на період до 2030 року, серед напрямів яких передбачено забезпечення гендерної рівності, розширення прав і можливостей усіх жінок та дівчат [6].

Важливим пріоритетом реалізації державної гендерної політики є також розвиток національного законодавства у сфері подолання дискримінації та домашнього насильства. 3 метою уніфікації підходів і забезпечення послідовності та сталості в діяльності державних органів щодо забезпечення рівності прав і можливостей для всіх людей у 2012 році було прийнято Закон України «Про засади запобігання та протидії дискримінації в Україні». Згідно з положеннями цього Закону «державна політика щодо запобігання та протидії дискримінації спрямована на: недопущення дискримінації; застосування позитивних дій; створення умов для своєчасного виявлення фактів дискримінації та забезпечення ефективного захисту осіб та/або груп осіб, які постраждали від дискримінації; виховання і пропаганду серед населення України поваги до осіб незалежно від їх певних ознак; поширення просвітницької діяльності у цій сфері» (стаття 7).

Новим імпульсом для розвитку гендерної політики в Україні стала Угода про асоціацію з Свропейським Союзом. Зокрема, прийнятим у 2014 році Законом України «Про внесення змін до деяких законодавчих актів України щодо запобігання та протидії дискримінації» визначення «дискримінації» приведено у відповідність до статті 1 Конвенції «Про ліквідацію всіх форм дискримінації щодо жінок». Нове визначення дискримінацію трактує як ситуацію, «...за якої особа та/або група осіб за їх ознаками раси, кольору шкіри, політичних, релігійних та інших переконань, статі, віку, інвалідності, етнічного та соціального походження, громадянства, сімейного та майнового стану, місця проживання, мовними або іншими ознаками, які були, є та можуть бути дійсними або припущеними, зазнає обмеження у визнанні, реалізації або користуванні правами і свободами в будь-якій формі, встановленій цим Законом, крім випадків, коли таке обмеження має правомірну, об'єктивно обгрунтовану мету, способи досягнення якої є належними та необхідними» (пункт 2 частини першої).

У 2017 році також відбулася знакова подія, що зробила цей рік переломним у питаннях прав людини. У грудні 2017 року Верховна Рада ухвалила Закон України «Про запобігання та протидію домашньому насильству», який набув чинності з 7 січня 2018 року.

У новому Законі України «Про запобігання та протидію домашньому насильству» запропоновано інноваційний підхід (із використанням європейських стандартів) до боротьби із цим негативним явищем у суспільстві. Під домашнім насильством тепер розуміється будь-яка дія фізичного, сексуального, психологічного або економічного насильства, а також погрози вчинення таких діянь. Постраждалими визнаються особи, незалежно від того, чи проживають вони спільно зі своїми кривдниками, чи ні (наречені, подружжя, колишнє подружжя, мати, батько, діти, їхні батьки, брати, сестри, нерідні батьки, опікуни, піклувальники, їхні діти, прийомні діти, діти-вихованці, інші родичі до двоюрідного ступеню зв'язку, особи, які спільно проживали або проживають однією сім'єю, але не перебувають у шлюбі, їх діти та батьки) та особи, які проживають разом (будь-які інші родичі, люди, які пов’язані спільним побутом, мають спільні права та обов'язки).

Із метою протидії проявам психологічного, фізичного, економічного, сексуального насильства, що вчиняються стосовно малолітньої чи неповнолітньої особи або такою особою стосовно інших учасників освітнього процесу, внаслідок чого могла бути чи була заподіяна шкода психічному або фізичному здоров'ю потерпілого, схвалено Закон України «Про внесення змін до деяких законодавчих актів України щодо протидії булінгу (цькуванню)». Закон вперше юридично закріплює поняття булінгу в українському законодавстві та передбачає відповідальність не тільки за вчинення, але й за приховування випадків булінгу [8].

Крім того, в жовтні 2018 року Уряд затвердив Концепцію Державної соціальної програми запобігання та протидії домашньому насильству та насильству за ознакою статі на період до 2023 року. Метою програми є забезпечення розбудови системи запобігання та протидії домашньому насильству та насильству за ознакою статі відповідно до міжнародних стандартів і Закону України «Про запобігання та протидію домашньому насильству» в умовах децентралізації та запровадження комплексних дій та заходів, спрямованих на зменшення масштабу такого явища.

Важливим завданням є також розвиток гендерно-чутливого законодавства в секторі безпеки і оборони. У зв'язку із цим та з метою підвищення рівня дотримання принципу забезпечення рівних прав та можливостей жінок і чоловіків у всіх сферах життя суспільства розпорядженням Кабінету Міністрів України від 24 лютого 2016 року № 113-р затверджено Національний план дій із виконання резолюції Ради Безпеки ООН 1325 «Жінки, мир, безпека» на період до 2020 року.

Верховною Радою України у 2018 році також прийнято Закон «Про внесення змін до деяких законів України щодо забезпечення рівних прав і можливостей жінок і чоловіків під час проходження військової служби у Збройних Силах України та інших військових формуваннях». Його реалізація сприятиме підвищенню рівня правового захисту військовослужбовців-жінок, сприятиме збільшенню кількості жінок на військовій службі, зокрема на вищих військових посадах. 
Реалізація гендерно чутливої політики має забезпечити рівний доступ жінок і чоловіків до ухвалення рішень на державному рівні, зокрема $з$ метою більш рівномірного представлення інтересів різних соціальних груп як в Українському Парламенті, так і в органах місцевого самоврядування. Досягненню цієї мети слугує такий інструмент залучення жінок у політику, як гендерні квоти, що можуть бути як законодавчими (регульованими державою), так і добровільними (закріпленими на рівні партій; такий підхід більш популярний у світі). Слід зазначити, що квоти є одним із інструментів «позитивних дій».

Висновки з даного дослідження і перспективи подальших розвідок у даному напрямку. В умовах реалізації широкомасштабної реформи державного управління важливим завданням є упровадження стандартів гендерної рівності в діяльність усіх органів державної влади. Одним із найбільш пріоритетних завдань реалізації державної гендерної політики в Україні на сучасному етапі є створення нормативно-правової бази 3 питань гендерної рівності, яка поступово приводиться у відповідність до міжнародних стандартів.

На всіх етапах реалізації Стратегії реформування державного управління України на період до 2021 року, схваленої розпорядженням Кабінету Міністрів України від 24 червня 2016 року № 474-р, передбачено здійснення відповідних заходів щодо забезпечення гендерної рівності як складової частини принципів державного управліннях. Стратегія спрямована на розв’язання, зокрема, і гендерного дисбалансу у сфері державної служби та управління людськими ресурсами.

Важливим пріоритетом реалізації державної гендерної політики є також розвиток національного гендерного законодавства у сфері подолання дискримінації та домашнього насильства, а також у сфері безпеки та оборони.

Необхідним завданням подальшої реалізації парламентської реформи є створення сприятливих умов для покращення можливостей доступу жінок до політики, забезпечення паритетного представництва жінок та чоловіків у парламенті. Разом із тим є доцільним інтенсифікувати наукові дослідження з питань реалізації гендерно чутливої політики та забезпечення рівного доступу жінок і чоловіків до ухвалення рішень на державному рівні, рівномірного представлення інтересів різних соціальних груп в усіх органах державної влади тощо.

\section{Список використаних джерел:}

1. Доповідь та дорожня карта щодо внутрішньої реформи та підвищення інституційної спроможності Верховної Ради України. Підготовлено з оцінки потреб під головуванням П. Кекса, Президента Свропейського Парламенту у 2002-2004 роках. Брюсель, 2016 р. 89 с. URL : https://www.europarl.europa.eu/resources/library/media/201 60301RES16508/20160301RES16508.pdf.

2. Закон України «Про державну службу» від 10 грудня 2015 року № 889-VIII. URL : https://zakon.rada.gov.ua/ laws/show/889-19.

3. Марценюк Т. Гендер для всіх. Виклик стереотипам. Київ : Основи, 2017. 256 с.

4. Марценюк Т. Гендерна політика Європейського Союзу: загальні принципи та найкращі практики. Київ : Міжнародний центр перспективних досліджень, 2015. 44 с.

5. Про заходи з реалізації рекомендацій щодо внутрішньої реформи та підвищення інституційної спроможності Верховної Ради України : Постанова Верховної Ради від 17 березня 2016 року № 1035-19. URL : https://zakon.rada.gov.ua/laws/show/1035-19.

6. Офіційний сайт Верховної Ради України. URL : https://rada.gov.ua/en.

7. Analyzing Gender. Women and Men in Development. Stockholm : SIDA, 2003.

8. Desk Research of the Surveys of IDPs. UNHCR, December 2017.

9. Hermet G., Badie B., Birnbaum P. Dictionnaire de la science politique et des institutions politiques. 3ème éd. Paris : Dalloz, 2001. 287 p.

10. Raynaud P., Rials S. Dictionnaire de philosophie politique. Paris : PUF, 1996. 395 p.

11. Shcherbak N. Civil service reform in Ukraine: current status and new objectives to be attended. Nauka I Studia, Przemysl. 2014. № 10(120). P. 94.

12. Global Issues. Governance / United Nations. URL : https://www.un.org/en/globalissues/governance.

\section{References:}

1. European Parliament (2016). Dopovid ta dorojnia karta chodo vnutrishnioyi reform ta pidvychennia istytutsiynoi spromojnosti Verkhvnoi Rady Ukrainy. Pidgotovleno z otsinky potreb pid golovuvanniam P. Koksa [Report and roadmap on internal reform and institutional capacity building of the Verkhovna Rada of Ukraine. Prepared for the needs assessment chaired by P. Keks, President of the European Parliament in 2002-2004]. Brussels, 89 p. URL: https://www.europarl. europa.eu/resources/library/media/20160301RES16508/20160301RES16508.pdf [Ukraine].

2. VRU (2015) Pro derjavnu slujbu: Zakon Ukrainy [On Civil Service: Law of Ukraine] URL: https://zakon.rada.gov.ua/laws/show/889-19 \{Last accessed: 11.08.2020\} [Ukraine].

3. Marzenuk T. (2017) Gender dlia vsikh. Vyklyk stereotypam [Gender for all. A challenge to stereotypes]. Osnovy. Kyiv. 256 p. [Ukraine]. 
4. Marzenuk T. (2015) Genderna polityka Evropeyskogo Soiuzu: zagalni pryntsypy ta naykrachi praktyky. [Gender policy of the European Union: general principles and best practices]. Kyiv. 44 p. [Ukraine].

5. VRU (2016) Pro zakhody z realisatsii rekomendatsiy chodo vnutrishnioyi reform ta pidvychennia instytutsiynoyi spromozhnosti Verkhovnoi Rady Ukrainy: Postanova Verkhovnoi Rady Ukrainy. [On measures to implement recommendations on internal reform and increase the institutional capacity of the Verkhovna Rada of Ukraine: Resolution of the Verkhovna] URL: https://zakon.rada.gov.ua/laws/show/1035-19 \{Last accessed: 11.08.2020\} [Ukraine].

6. Official site of the Verkhovna Rada of Ukraine. URL: https://rada.gov.ua/en \{Last accessed: 11.08.2020\}. [Ukraine].

7. Analyzing Gender. Women and Men in Development (2003). SIDA. Stockholm. [Sweden].

8. Desk Research of the Surveys of IDPs. - UNHCR, December 2017.

9. Hermet G., Badie B., Birnbaum P. (2001) Dictionnaire de la science politique et des institutions politiques. 3ème éd. Dalloz. Paris. 287 p. [France].

10. Raynaud P., S.Rials (1996) Dictionnaire de philosophie politique. PUF. Paris: 395 p. [France].

11. Shcherbak N. (2014) Civil service reform in Ukraine: current status and new objectives to be attended. Nauka I Studia, Przemysl, № 10 (120). P. 94

12. Global Issues. Governance / United Nations. URL: https://www.un.org/en/globalissues/governance \{Last accessed: 11.08 .2020$\}$. 